\title{
Informasi Pengelolaan dan Pencatatan Kas Kecil pada CV. Mulia Frozindo Berbasis
} Aplikasi Web Accounting

\author{
${ }^{1}$ Citra Istinasari, ${ }^{2}$ Soesilawati Soema Atmadja \\ ${ }^{1-2}$ STIE Mahardhika
}

Article history

Received : 24 July 2021

Revised. : 10 September 2021

Accepted : 10 September 2021

*Corresponding Author:

Citra Istinasari

STIE Mahardhika

Email:

citraissa@gmail.com

\begin{abstract}
Petty cash has a vital role in organizational functional training/training. Trivial money is usually used in keeping an eye on the small real exchanges that occur on a daily basis. The object of this research is CV. Mulia Frozindo which is one of the companies engaged in the design, supply, install, and maintenance of facilities/coolants (frozen/coolant). In cash management and accounting records, especially for petty cash funds in CV. Mulia Frozindo is still handled by one section, namely the admin section. With the large amount of transaction data that occurs, if the information collection is done physically, a lot of time is wasted on handling financial information considering that there are many stages that must be completed. Therefore, the resulting information is not really accurate and precise. Because of this, an accounting web application has been created to make it easier to make decisions on the business being run. The use of web accounting applications is very efficient and effective for an entrepreneur in running his business. Financial data processing that only inputs transaction data can produce the desired report for decision making.
\end{abstract}

Keywords: Petty Cash, Information Systems, Web Accounting Applications

\section{PENDAHULUAN}

Tingkat kompetisi didalam dunia bisnis semakin melebar. Kondisi tersebut bisa dilihat dari semakin banyak perusahaan yang berdiri baik itu milik Negara, swasta ataupun pihak asing. Dengan tujuan bahwa sistem informasi akuntansi adalah bagian yang tidak dapat dibedakan dari dunia bisnis. Sistem informasi telah menjadi kebutuhan penting dari kehidupan, termasuk dalam area bisnis, karena banyak kemudahan-kemudahan yang ditimbulkan. Sistem Informasi amat diperlukan untuk menyelamatkan kelangsungan suatu perusahaan. Selain dari sumber daya manusia, tiap-tiap perusahaan mempunyai sumber daya keuangan. Pengaturan sumber daya keuangan dalam perusahaan adalah kunci utama untuk pelaksanaan fungsional operasi perusahaan dan tidak tidak dapat dipisahkan dari kegiatan yang terkait dengan yang dinamakan uang.

Salah satu keterangan yang diperlukan oleh perusahaan yaitu merupakan keterangan tengan keluarnya uang perusahaan. Keterangan ini amat penting karena menjadi salah satuy penentu kelancaran usaha suatu perusahaan dan membantu pimpinan dalam melihat perubahan posisi kas dalam suatu periode tertentu yang dilihat dari pengeluaran kas yang berkaitan dengan aktivitas operasi bisnisnya. Dalam menjalankan fungsi-fungsinya, salah satu kerangka kerja yang diandalkan untuk membantu terwujudnya perusahaan yang baik adalah pengaturan pengendalian dan pengawasan uang dan pengembangan serta pengelola uang. Kerangka kerja ini membutuhkan pertimbangan yang luar biasa karena mengidentifikasi dengan kapasitas perusahaan untuk menangani sumber dayanya. Uang 
perusahaan termasuk dalam bagian dari sumber daya keuangan yang butuh pengurusan yang benar agar kehidupan perusahaan bisa berlangsung terutama kas kecil karena kas kecil adalah pengeluaran uang yang jumlahnya kecil dan biasanya terjadi setiap harinya. Pada pengeluaran kas perusahaan terdapat dana kas kecil, kas kecil ini dipergunakan untuk membiayai berlangsungnya perusahaan setiap harinya dan yang nilai nominalnya tidak terlalu besar.

Santioso, Yuniarwati, Ekadjaja, dan Rasyid, 2017) berpendapat bahwa "kas kecil atau biasa disebut kas kecil berarti perusahaan menyediakan uang tunai untuk menutupi pengeluaran yang relatif kecil dan tidak ekonomis.

Sedangkan pendapat (Erhans, 2016), "kas kecil adalah kas tunai yang disuguhkan untuk pengeluaran yang relatif kecil, seperti pembelian ATK dan perangko.

Sementara itu, pendapat Ardiyos (Atika \& Pusung, 2018), "kas kecil mengacu pada sejumlah kas tunai atau uang tunai yang disuguhkan untuk memenuhi kebutuhan seharihari perusahaan, dan jumlahnya relatif sedikit". Modal kas kecil diamanahkan kepada pegawai yang memegang kas kecil dan bertanggung jawab atas pengelolaan dana kas kecil tersebut. Kas kecil memiliki beberapa karakteristik. Pendapat (Yuniarwati, Santioso, Ekadjaja, \& Rasyid, 2017) karakteristik tersebut adalah:

1. Nilainya dikontrol tidak melebihi atau tidak kurang dari suatu nilai tertentu yang sudah ditetapkan oleh manajemen perusahaan. Setiap perusahaan memiliki ketetapan nilai yang berbeda-beda disesuai dengan ukuran fungsional perusahaan.

2. Dipakai untuk mendanai transaksi yang nominalnya relatif sedikit dan biasanya transaksi rutin setiap hari.

Keuntungan menggunakan sistem komputerisasi untuk pengolahan data adalah mampu menyusun data dengan lekas dan tepat (Hernandez, \& Damayanti, 2018). Selain itu penggunaan sistem komputerisasi untuk pengolahan data juga bisa menyusun data dalam jumlah besar, jika membayar dengan cek/bilyet giro dapat menyimpan berkas atau dokumen dengan benar tanpa membutuhkan banyak tempat. CV. Mulia Frozindo merupakan perusahaan yang bergerak di bidang design, supply, install, dan maintenance untuk frozen facilities/pendingin. Perusahaan ini sudah berdiri sejak 1 Desember 2004. Awalnya perusahaan ini bertempatkan di Surabaya, tetapi pada saat ini berpindah di Pergudangan 88 Blok C-1, Sedati, Juanda, Sidoarjo. Dalam perkembangannya CV. Mulia Frozindo aktif memberikan pelatihan terhadap teknisinya untuk mengikuti perkembangan teknologi refrigerasi terkini.

Dalam mengelola kas kecil CV. Mulia Frozindo menunjuk admin sebagai pencatat dan pengolah data untuk membuat laporan pengeluaran kas kecil dan proses pengolahan data tersebut terdapat aktifitas pemrosesan data dan pelaporannya yang sudah terkomputerisasi namun terbatas hanya mempergunakan Microsoft Excel yang bisa dibilang program aplikasi komputer yang masih sederhana. Proses pendataannya masih rumit dengan mengunakan buku besar sehingga membutuhkan ketelitian. Dan metode pencatatan data pada form bukti kas masuk-keluar dan buku laporan juga masih digunakan. Dengan digunakannya metode tersebut timbul beberapaan permasalahan yaitu permasalahan ketidakefisiesian waktu, ketidakefisiensian kertas, kehilangan data transaksi dan tidak terbaharuinya laporan kas sering terjadi.

Penelitian ini bermaksud merancang suatu sistem informasi penerimaan dan pengeluaran kas kecil berbasis website untuk menyimpan informasi-informasi transaksi dan informasi penggunanya. Manfaat riset ini adalah bisa menolong mencari kelemahan sistem yang ada saat ini, dapat merekomendasikan cara keluar dari permasalahan tersebut yang dilihat dari hasil identifikasi permasalahan, dapat melahirkan serangkaian pengurusan dan pengontrolan internal. 


\section{TINJAUAN PUSTAKA \\ Kas Kecil}

Dana kas kecil merupakan dana yang meliputi bayar membayar, yang tidak mempergunakan cek akan tetapi mempergunakan kas tunai. Karakteristik tersebut adalah:

a. Nilainya dikontrol tidak melebihi atau tidak kurang dari suatu nilai tertentu yang sudah ditetapkan oleh manajemen perusahaan. Setiap perusahaan memiliki ketetapan nilai yang berbeda-beda disesuai dengan ukuran fungsional perusahaan.

b. Dipakai untuk mendanai transaksi yang nominalnya relatif sedikit dan biasanya transaksi rutin setiap hari.

Maksud dibuatkannya kas kecil adalah guna menangani masalah perangkat keras/persediaan kantor yang dialami oleh bagian di tempat kerja, menghindari teknik cicilan yang tidak ekonomis juga tidak masuk akal untuk biaya yang umumnya kecil dan tidak terduga, dan juuga memfasilitasi bobot pekerja staf dalam menawarkan dukungan maksimal kepada klien juga termasuk pelopor hubungan bisnis.

\section{Sistem Informasi Akuntasi}

Sistem informasi adalah kumpulan sumber daya manusia dan alat yang didesain untuk mentransformasikan dana transaksi keuangan atau laporan keuangan menjadi suatu informasi yang memiliki nilai untuk membantu perusahaan dalam mengambil keputusan.

\section{Aplikasi Web Accounting}

Situs atau website dapat diartikan sebagaai himpunan beranda-beranda yang dipergunakan untuk memperlihatkan tulisan, , animasi, suara, video, gambar diam atau gerak dana atau kombinasi dari semuanya baik yang bersifat statis maupun dinamis yang membentuk satu rangkaian bangunan yang saling terkait, yang masing-masing dikairtkan dengan jaringan-jaringan beranda. (Bank et al., 2020). Website Accounting merupakan software manajemen bisnis yang memfasilitasi keringanan dalam menata dan mengutarakan laporan dari berbagai kegiatan bisnis. Tujuan aplikasi web accounting ini adalah sebagai peringan instans dalam penyusunan laporan keuangan.

\section{Penelitian Terdahulu}

Penelitian dahulu bermaksud untuk memperoleh indikasi pertimbangan dan referensi. Dan juga, untuk menjauhkan fitnah dengan beranggapan penjiplakan pada penelitian laiinya. Sehingga pada penelitian ini dicantumkan hasil-hasil penelitian dahulu sebagai berikut :

Hasil penelitian Eulin Karlina, Fajri Ariandi, Siti Dedeh Humaeroh, dan Rini Martiwi. (2019). Penelitiannya berjudul "ANALISIS PELAKSANAAN PENCATATAN PETTY CASH (KAS KECIL) PADA PT MNI ENTERTAINMENT JAKARTA PUSAT”. Penelitian ini merupakan penelitian yang memakai metode kualitatif. Yang dihasilkan dalam penelitian ini adalah Pelaksanaan penyusunan kas kecil pada PT MNI Entertainment Jakarta Pusat sebagai berikut dengan mempergunakan metode imperst, dimana dalam metode ini penetapan jumlah dana kas kecil selalu tetap.(Karlina et al., 2019).

Hasil penelitian Iwan Kurniawan (2020). Penelitian Iwan Kurniawan (2020) berjudul "PERANCANGAN APLIKASI DATA KARYAWAN BERBASIS ANDROID". Penelitian ini merupakan penelitian yang menggunakan metode kualitatif. Hasil dari penelitian ini adalah Pengembangan aplikasi menggunakan metode extreme programming yang memiliki fase-fase seperti planning, design, coding, dan testing. Aplikasi dibuat menggunakan software Android Studio. Hasil dari pengembangan aplikasi ini adalah suatu 
aplikasi yang berisi informasi mengenai data karyawan dan data pekerjaan yang terdapat dalam sebuah perusahaan (Kurniawan, 2020).

Hasil penelitian Fird Pangkey, Sabijono Harijanto, dan Tinangon Jantje (2015). Berjudul "EVALUASI PENERAPAN AKUNTANSI KAS KECIL PADA PT.SINAR PURE FOODS BITUNG". Dalam riset ini dipergunakan metode kualitatif. Hasil dari penelitian ini adalah metode yang digunakan dalam penyelesaian dana kas kecil, oleh PT. Sinar Pure Foods Bitung yaitu metode fluktuasi, dimana dalam metode ini saldo rekening kas kecil tidak tetap berfluktuasi sesuai dengan jumlah pengisian kembali dan pengeluaranpengeluaran kas kecil (Sinar et al., n.d.).

\section{METODE PENELITIAN}

Metode kualitatif dengan strategi studi kasus merupakan teknik yang dipakai pengarang pada penelitian ini. Berdasarka pendapat Wahyuni (2012:2) teknik penelitian kualitatif adalah teknik penulisan yang diperluas dipengetahuan sosial untuk menyelami studi sosial dan fenomena sosial yang kejadian pada masyarakat. Selain itu, dari segi metode riset ini mengadopsi metode studi kasus. Studi lapangan adalah cara memperoleh keterangan data yang diperlukan dan akan mendapatkan gambaran perihal kejadian secara langsung lewat bersosialisasi tatap muka dengan para pelaksana didalam penelitian. Studi lapangan meliputi tanya jawab, eksplorasi, dan pengarsipan. Didalam riset ini, pertanyaanpertanyaan tentang riset ditanyakan langsung oleh penulis kepada beberapa bagian staf CV. Mulia Frozindo. Penyelidikan dilaksanakan pada kegiatan-kegiatan yang berkaitan dengan perputaran keuangan kas kecil CV. Mulia Frozindo. Riset ini dilaksanakan di Sidoarjo dan riset bermulai pada tanggal 26 April 2021.

\section{HASIL DAN PEMBAHASAN}

\section{A. Definisi dan Konsep Literasi Keuangan}

Menurut Kamus Besar Bahasa Indonesia, Literasi merupakan kemampuan menulis danmembaca, pengatahuan atau keterampilan dalam bidang atau aktivitas tertentu dengan kemapuan individu mengolah informasi dan pengetahauan untuk kecakapan hidup. Literasi berlaku pada semua bidang yang salah satunya juga bisa di gunakan dalam literasi keuangan.

Menurut Otoritas Jasa Keuangan, Literasi Keuangan merupakan pengetahuan, keterampialan dan keyakinan dalam mengelola keuangan untuk mencpaai kesejahteraan masyarakat. sehingga dari definisi itu dapat dibrikan klasidikasi literasi keuangan berdasrakan indicator pengetahuan, keterampilan dan sudah sampai emnyakini akan oengelolaan keuangan itu. Adapun tujuan literasi keuangan menurut Pengawas Otoritas Jasa Keuangan yakni :

1. Meningkatkan kualitas pengambilan keputusan keuangan individu, dan

2. Perubahan sikap serta perilaku individu dalam pengelolaan keuangan menjadi lebih baik, sheingga mampu menentukan dan memanfaatkan Lembaga, produk dan layanan jada keuangan yang sesuai dengan kebutuhan dan kemampuan konsumen dan atau masyrakat dana tangka mencapai kesejahteraan.

Literasi keuangan merupakan perancanaan dan pelaksanaan atas : edukasi keuangan dan pengembangan infrastruktur yang mendukung litersi keuangan bagi konsumen.

Oleh karena itu, disamping hasil penelitian yang mendapati bahwa literasi keuangan masyarakat Indonesia itu rendah, maka pemerintah mengeambil peran dalam perbaikannya, yakni dengan cara melakukan serta memberikan edukasi keuangan dan pengembangan 
infrastruktur yang mendukung literasi keuangan bagi konsumen dan atau masyrakat. Materi CV. Mulia Frozindo merupakan perusahaan yang bergerak di bidang design, supply, install, dan maintenance untuk frozen facilities/pendingin. Perusahaan ini sudah berdiri sejak 1 Desember 2004. Awalnya perusahaan ini bertempatkan di Surabaya, tetapi pada saat ini berpindah di Pergudangan 88 Blok C-1, Sedati, Juanda, Sidoarjo. Dalam perkembangannya CV. Mulia Frozindo mendapatkan kepercayaan oleh beberapa principal dengan brand terkenal (Bitzer, Muller, Guntner dll ) untuk menjadi authorized distributor nya di Indonesia, dan berjalan hingga kini. CV. Mulia Frozondo juga beberapa kali mendapatkan penghargaan sebagai partner terbaik dari principal tersebut. CV. Mulia Frozindo mendapatkan penghargaan karena komitmennya yang selalu dijalankannya yaitu untuk memberikan servis yang terbaik untuk para customer baik itu product knowledge, design, after sales service, serta komitmen selalu memberikan product original. Untuk pengembangan SDM, CV. Mulia Frozindo aktif memberikan pelatihan terhadap teknisinya untuk mengikuti perkembangan teknologi refrigerasi terkini.

Berdasarkan analisis yang dilakukan peneliti, dalam mengelola kas kecil CV. Mulia Frozindo menunjuk admin selaku penulis dan penyusun data untuk menciptakan laporan pengeluaran kas kecil, dan proses pengolahan data tersebut terdapat aktifitas pemrosesan data dan pelaporannya. Sistem beserta teknik penulisan kas kecil yang sedang dilakukan selama ini di CV. Mulia Frozindo cukup berjalan baik tetapi masih menghabiskan banyak waktu yaitu orang yang melakukan pengajuan anggaran setiap saatnya harus menanyakan ke bagian admin, jika dalam pencatatan ada kendala saat cash opname, jadi sangatlah rawan, sedangkan dalam pencatatan diperlukan keakuratan dan ketelitian karena admin wajib menghitung uang yang nilainya banyak dan memiliki tanggung jawab selain itu juga. Disamping itu, penulisan data pengeluaran biaya operasional masih mempergunakan lembar kas masuk atau keluar dan Microsoft Excel yang dapat membuat sering terjadinya salah penulisan, lembar hilang, dan memerlukan waktu yang lama. Sistem tersebut dinilai kurang bagus dan boros waktu, Akhirnya ada kalanya bertemu kelalian yang tidak diharapkan dan tidak disengaja (human error). Security dokumen belum tentu dapat dijamin, akhirnya dokumen gampang hilang atau lupa dalam penyimpanannya, pembuatan laporan belum tentu akurat karena masih menghitung dan membuat laporan secara manual, yang dapat menyebabkan kesalahan yang tidak perlu.

Pada penelitian kali ini, peneliti menggunakan program aplikasi web accounting yang dapat mempermudah sistem pembuatan laporan keuangan khususnya laporan pengeluaran dan pemasukan kas kecil. Aplikasi web accounting ini sudah terprogram, hanya langkah-langkah mudah penginputan sudah dapat menghasilkan laporan yang diinginkan.

Berikut penginputan pada program aplikasi web accounting:

1) Memasukkan Pencatatan Transaksi Kas Keluar

Cara memasukkan uang keluar, gunakan Modul Kas dan Bank - Kas Keluar. Uang keluar dipergunakan sebagai informasi atau pencatatan transaksi seperti bayar PDAM, PLN, kunjungan kerja,uang jasa, telepon, wifi, uang saku, bayar cicilan, tagihan, biaya administrasi, dan lain-lain. 


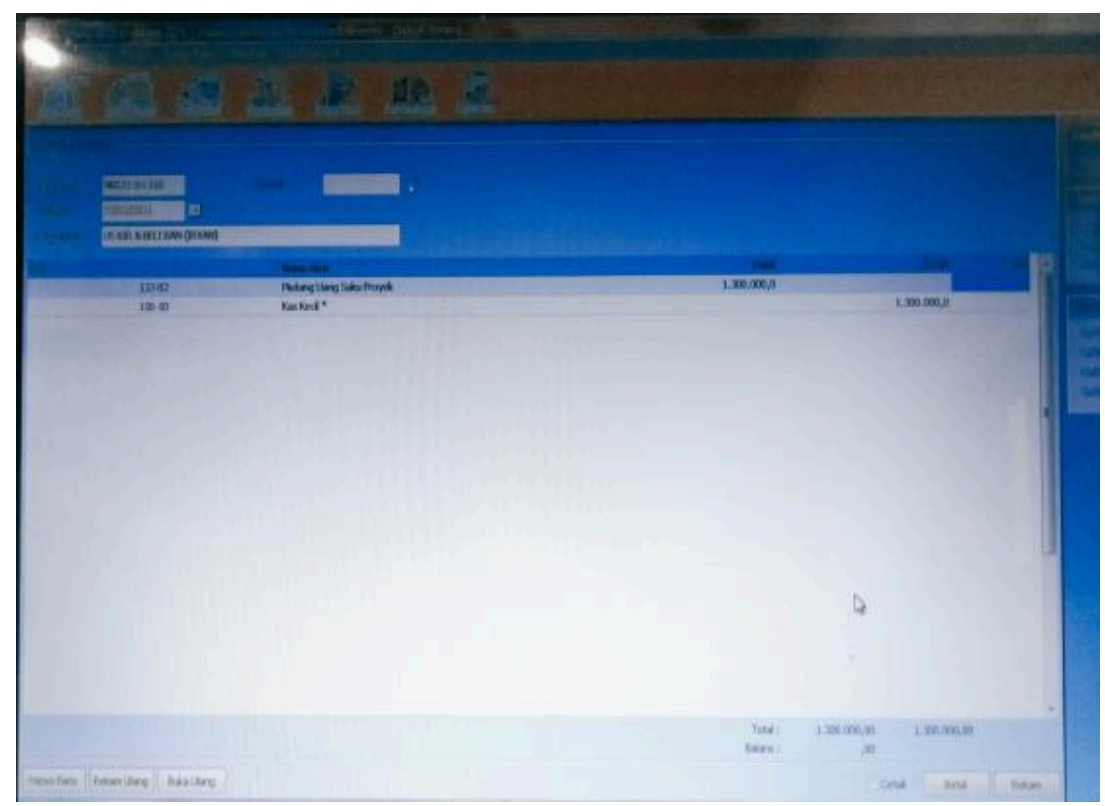

Gambar 1. Contoh Penginputan Kas Keluar

2) Memasukkan Pencatatan Transaksi Pembelian

Semua yang dibeli dapat dimasukkan atau dicatat melalui akun pembelian barang dagangan (invoicing). Transaksi pembelian ini dengan otomatis akan membuat pembukuan jurnal akuntansi, menambah stok barang yang ada dan memperbarui kartu kewajiban (kartu hutang). Silahkan mengisi nama suplier atau pemasok, pilih jenis barang yang telah dibeli, jumlah barang dan nilainya, kemudian klik tombol record, kemudian, pada saat itu semua siklus pembukuan akan dilakukan secara berurutan.

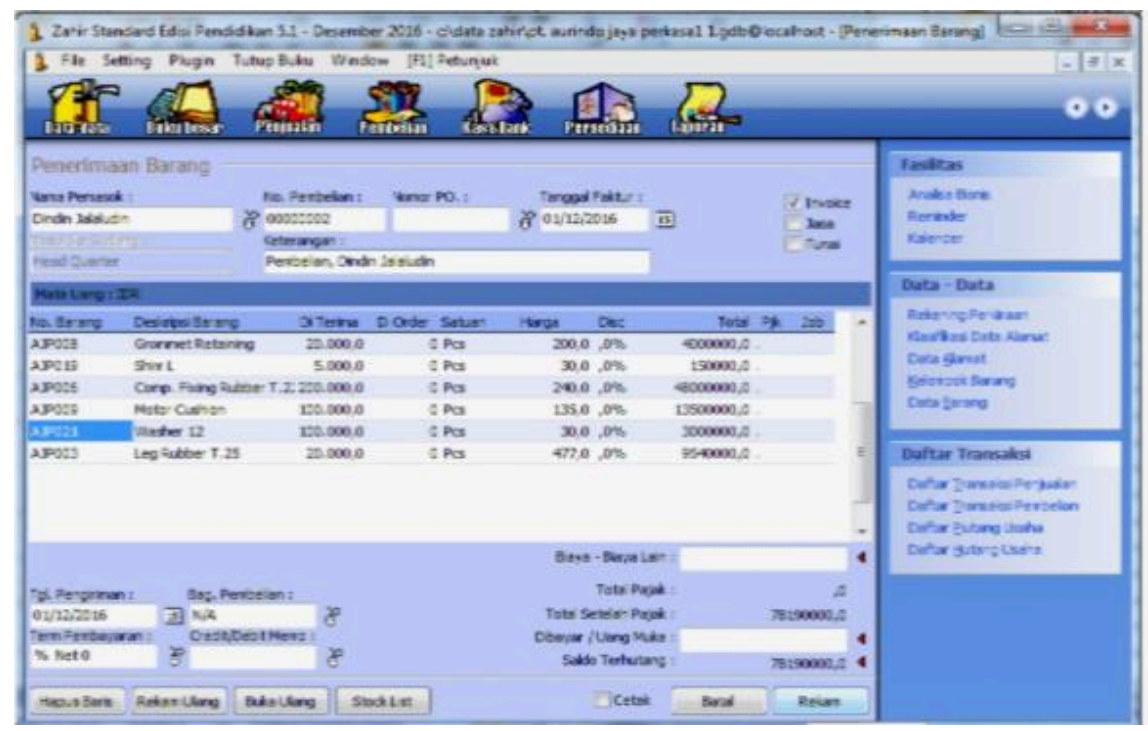

Gambar 2. Contoh Penginputan Pembelian

\section{3) Memasukkan Pencatatan Transaksi Penjualan}

Semua jenis transaksi penjualan barang maupun jasa dapat dimasukkan atau dicatat dalam transaksi pengiriman barang dagangan (faktur penjualan). Transaksi penjualan ini secara otomatis akan membuat pembukuan jurnal akuntansi, mengurangi stok yang ada dan memperbarui kartu piutang. Silahkan mengisi identitas pembeli/klien, pilih barang 
dagangan/jasa yang akan dijual, lalu tekan tulisan record, Selanjutnya semua siklus pembukuan akan dilakukan secara berurutan. Klik Modul Penjualan - Pengiriman Kargo.

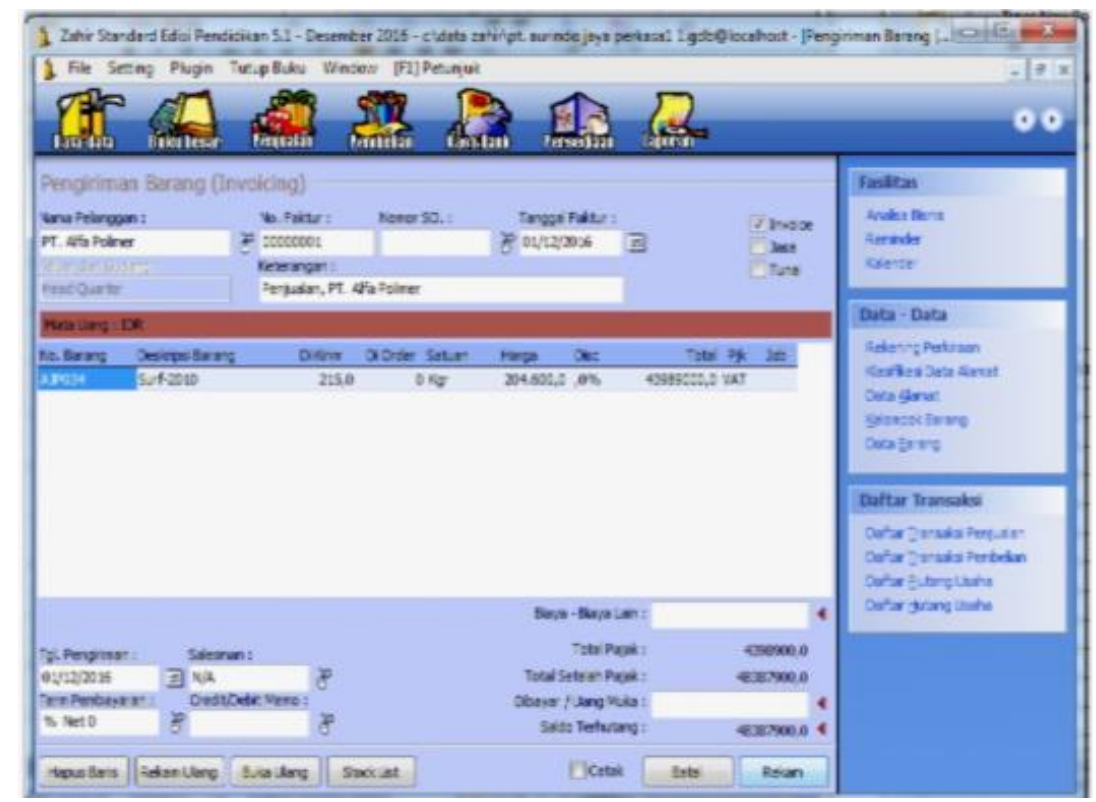

Gambar 3. Contoh Penginputan Penjualan

4) Memasukkan Pencatatan Transaksi Pembayaran Utang

Apabila telah melakukan pembayaran hutang, maka transaksi pembayaran hutang dapat dicatat dalam akun pelunasan hutang usaha, ketik atau memilih suplier yang akan menerima uang tersebut, selanjutnya lanjutkan memilih nomor faktur atau invoice mana yang akan dibayar, menulis potongan pelunasan jika terdapat diskon, dan pembayaran penalti terlambat membayar apabila ada.

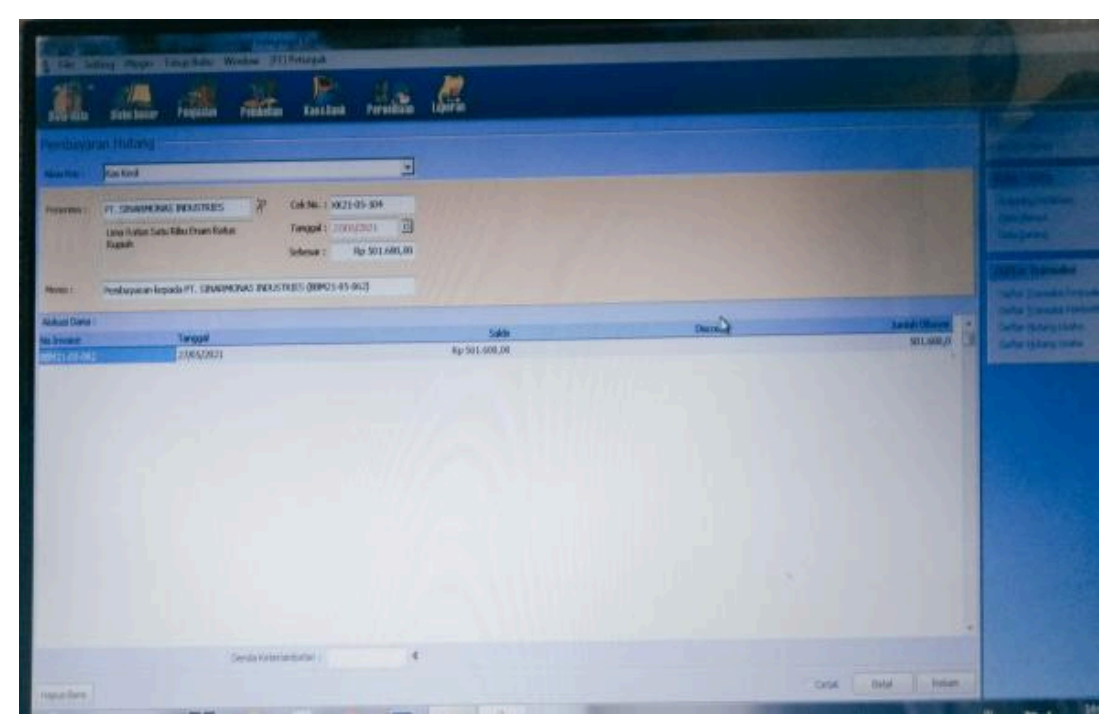

Gambar 4. Contoh Penginputan Pembayaran Utang

5) Memasukkan Pencatatan Transaksi Piutang Masuk

Untuk menginput transaksi piutang yang sudah dibayarkan, dapat dicatat pada form penjualan usaha, pilih nama pelanggan yang sudah melunasi, lanjutkan memilih nomor 
faktur atau invoice mana yang sudah dilunasi, menulis potongan pembayaran apabila ada diskon yang diberikan dan denda terlambat membayar jika ada.

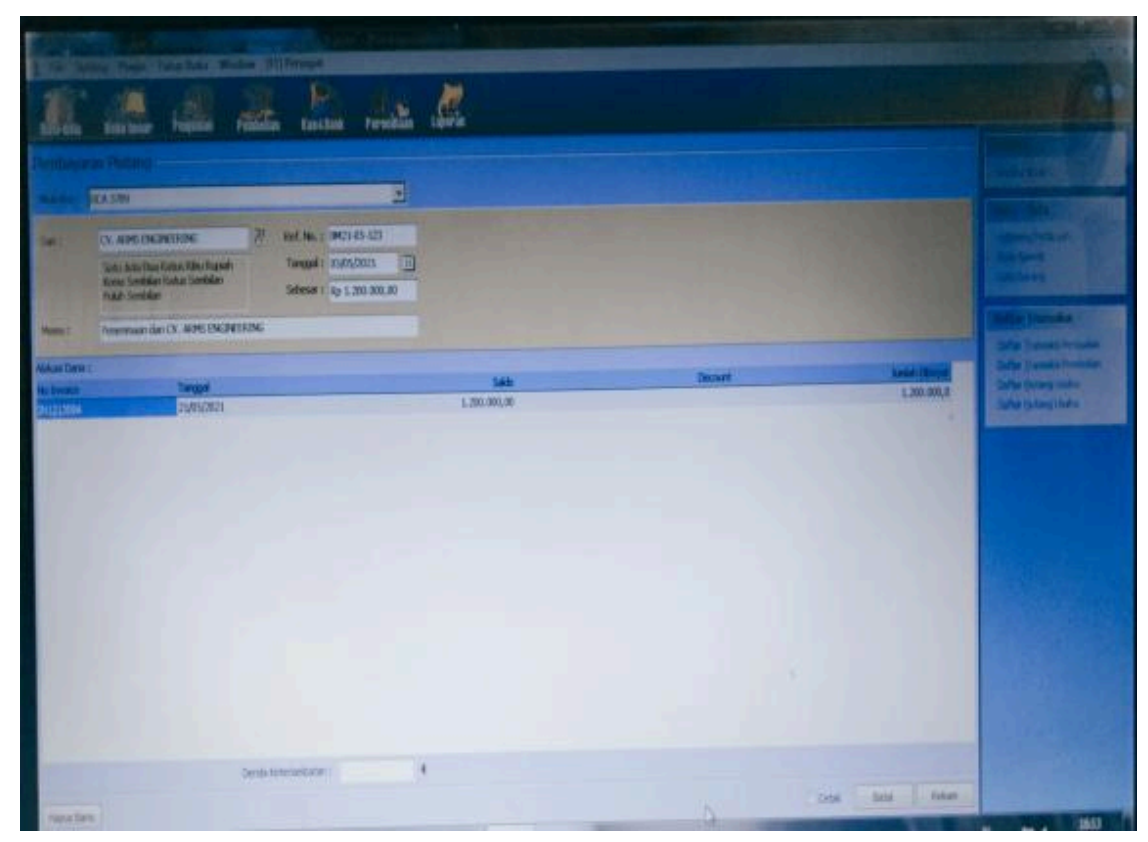

\section{Gambar 5. Contoh Penginputan Transaksi piutang masuk}

\section{KESIMPULAN}

Berdasarkan hasil dan pembahasan tentang pengelolaan data kas kecil pada CV. Mulia Frozindo diatas, maka dapat ditarik kesimpulan:

1. Pengolahan data akuntansi pada CV. Mulia Frozindo sudah terkomputerisasi namun hanya mempergunakan aplikasi program komputer yang dianggap sederhana yaitu Microsoft Excel. Dan metode pencatatan data ditulis pada form bukti kas masuk-keluar. Sehingga penyusunan laporan keuangan menjadi tidak efektif dan boros dalam hal waktu. Selain itu, juga dapat menyebabkan hambatan dalam membuat laporan, karena menghabiskan sebagian besar waktu untuk mencatat informasi data dan mencari data.

2. Dengan kerangka kerja yang masih seperti itu, dapat memungkin untuk melakukan pekerjaan double atau ganda, yang mendorong kontrol dan representasi yang salah oleh individu yang tidak dapat diandalkan.

3. Pemanfaatan aplikasi web accounting ini dapat menjadi pilihan berpikir kritis dalam menangani informasi data akuntansi pada CV. Mulia Frozindo. Meminimalisir kesalahan yang mungkin saja dapat terjadi dalam penanganan informasi data yang diselesaikan dan dapat mempercepat langkah penyusunan informasi akuntansi.

4. Aplikasi web accounting ini juga dapat mencepatkan dalam membuat laporan keuangan yang dilakukan oleh CV. Mulia Frozindo karena hanya tinggal memasukan atau menginputnya saja.

\section{SARAN}

Setelah kita bahas diatas. Penulis mencoba memberikan beberapa ide dengan harapan dapat bermanfaat bagi semua orang, sehingga framework dapat berjalan dengan baik. Ideide pencipta adalah sebagai berikut:

1. Penting untuk terus mempersiapkan para pekerja yang akan menggunakan aplikasi web accounting agar mereka dapat mengerjakan dan menjalankan aplikasi ini dengan baik. 
2. Dalam pengoperasian aplikasi web accounting, diharuskan kecermatan dan kontrol dari pengguna. Khususnya dalam hal pemasukan informasi data, regulasi yang benar harus diikuti agar output yang diperoleh secara otomatis sesuai dengan harapan.

3. Dalam penggunaan aplikasi web accounting, disarankan untuk memanfaatkan semua fasilitas yang disediakan seperti fasilitas pencadangan file data yang dapat dimanfaatkan untuk mencadangkan informasi data apabila terjadi kelenyapan folder atau hal yang tidak diinginkan lainnya.

\section{DAFTAR PUSTAKA}

Mulyadi. (2016). "Sistem Informasi Akuntansi”. Jakarta : Salemba Empat.

Harnanto (2013), Akuntansi Keuangan Menengah, Liberty, Yogyakarta.

Atika, L., \& Pusung, R. J. (2018). Ipteks Pengelolaan Kas Kecil ( Petty Cash ) Pada Pt. Pln (Persero) Unit Induk Pembangunan Sulawesi Bagian Utara. Ipteks Akutansi Bagi Masyarakat, 2(2), 370373

Bank, P. T., Berbasis, B., Achyani, Y. E., \& Velayati, A. (2020). Analisa dan Implementasi Sistem Informasi Pengeluaran Kas Kecil Pada. 22(1), 47-54.

Karlina, E., Ariandi, F., Humaeroh, S. D., \& Martiwi, R. (2019). Analisis Pelaksanaan Pencatatan Petty Cash (Kas Kecil) Pada PT MNI Entertainment Jakarta Pusat. 3(2), 233-240.

Kurniawan, I. (2020). PERANCANGAN APLIKASI DATA KARYAWAN. 01(04), 534-541.

Sinar, I. N., Foods, P., Fakultas, A., \& Ratulangi, U. S. (n.d.). EVALUASI PENERAPAN AKUNTANSI KAS KECIL PADA PT . SINAR PURE FOODS BITUNG EVALUATION OF APPLICATION OF ACCOUNTING FOR SMALL CASH. 15(04), 288-299. 